\title{
Analysis of the expansion of supply and demand of Speech-Language Pathology/Audiology courses in Brazil between 1994 and 2014
}

Keiner Oliveira Moraes(1) Urssula Aparecida Santos Leal Ribeiro(1) Renata Maria Moraes Moreira Furlan(1) Raphael Augusto Teixeira de Aguiar ${ }^{(1)}$

(1) Universidade Federal de Minas Gerais UFMG, Belo Horizonte, Minas Gerais, Brasil.

Conflict of interests: Nonexistent

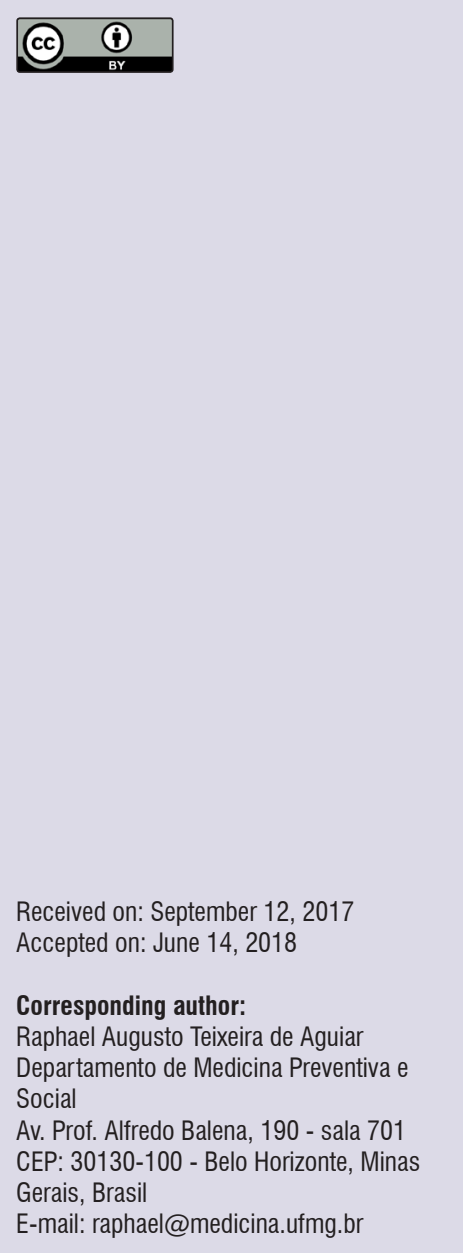

\section{ABSTRACT}

Objective: to analyze the offer of courses, vacancies, number of first year and final year students in Speech-Language Pathology/Audiology in Brazil between 1994 and 2014, as well as the number of applicants per vacancy and the ratio of final year students to million inhabitants.

Methods: search on the platform of the Sistema de Indicadores das Graduações em Saúde (SIGRAS - Health Under-graduation Indicator System) to obtain the number of courses, vacancies and first and final year students. From these data, the ratios of applicants to vacancy and of final-year students to million inhabitants were calculated, considering the demographic census. The data were analyzed according to the region of Brazil and to the legal nature of the institution.

Results: the number of courses, vacancies, first and final year students was higher in the Southeast region and in private institutions in all historical series. Since 2008, there has been a decrease in the number of courses and vacancies in the Southeast and a progressive increase in the Northeast and in the South of the country. The Northeast presented the largest ratio of applicants to vacancy in the historical series. There was an increase in the number of final year students per million inhabitants in the first decade analyzed, followed by a decrease.

Conclusion: regional inequality in the distribution of Speech-Language Pathology/ Audiology courses in Brazil, greater participation of the private sector and a progressive increase of the public sector are verified.

Keywords: Speech, Language and Hearing Sciences; Universities; Public Health 


\section{INTRODUCTION}

The record of the Speech-Language Pathology/ Audiology history in Brazil points to a strong influence of the educational institutions on the emergence of the profession 1 . The precursors of Speech-Language Pathology/Audiology were trained educators to act as "experts in word errors" or "speech therapists"2. The first courses on "Speech Therapy" were created in the early $1960 \mathrm{~s}^{1}$ and were aimed at training technologists in Speech Therapy. The first minimum curriculum setting the subjects and the hours of these courses was regulated by Resolution No. 54/76 of the Conselho Federal de Educação (Federal Council of Education) ${ }^{2}$.

During the 70's and early 80's, the SpeechLanguage Pathology/Audiology courses in Brazil lasted from two to three years, with course load of approximately 1,800 classroom hours and they trained technologists $^{2}$. After the profession was regulated, by law no. 6,965, in $1981^{3}$, the Conselho Federal de Educação (Federal Council of Education) transformed all training courses for technologists in full undergraduate courses in Speech-Language Pathology/Audiology through resolution no. 06/83. Since then, the areas and places of intervention of the speech-language pathologist have been growing, as well as the number of professionals, which reached 40,818 registered in the regional councils of Speech-Language Pathology/Audiology in May $2017^{4}$. The distribution of these professionals in national territory is quite uneven. The largest concentration is in the state of São Paulo, which houses approximately $30 \%$ of the professionals ${ }^{4}$.

In order to contribute to the planning and implementation of the training and professional insertion policies in the field of health, in 2006, a document was published with the trajectory of the undergraduate courses in the health area, including the Speech-Language Pathology/ Audiology, in the period 1991- 2004². The document shows that there was an increase in the number of courses in the analyzed period and that the highest concentration of courses was in the Southeast region. There was moderate growth in the South region and the highest growth occurred in the Northeast. The number of courses offered in the different regions of the country proved to be compatible with the population density found in each area. The private institutions expanded the offer of courses and vacancies in a more aggressive way than the public ones, and there was a reduction of the participation of the public institutions in the offer of vacancies in the analyzed period. The document also showed idleness of vacancy occupancy only in the private system and high student dropout rate.

Another study pointed, in Brazil, to an expansion in the number of vacancies with a decrease in the number of offer in private Higher Education Institutions (HEls) since 2008, which was explained by the possible lack of attractiveness of the labor market and by the difficulty of full insertion of the professional in the Sistema Único de Saúde (SUS - Brazilian public health service $)^{5}$. The trajectory of the profession points to a structuring of the undergraduate courses in SpeechLanguage Pathology/Audiology determined by the needs and possibilities of the labor market and by political, economical and social interests ${ }^{6}$. Research on the theme ${ }^{5,6}$ emphasizes the need to carry out new historical studies to stimulate discussions that contribute to the planning and implementation of professional training policies.

The scenario from 2004 to the present day has changed a lot and there is little information available in the literature for consultation by the professionals. With this research, it is intended to make available an analysis on the expansion of undergraduate courses accessible to professionals. It is important that the Speech-Language Pathology/Audiology professional know and understand the trajectory and trends of his/her profession so that he/she could reflect on the challenges and perspectives of his/her area and also for the accomplishment of the planning and implementation of higher education training policies in Speech-Language Pathology/Audiology. Therefore, the objective of this study was to analyze the expansion of courses and vacancies in Speech-Language Pathology/Audiology in Brazil, as well as the number of first and final year students, the ratio of candidates to vacancy and of first year students to million inhabitants in the period from 1994 to 2014, comparing the numbers obtained from their geographic regions and the legal nature of the institutions.

\section{METHODS}

Because this research involves only data sources of public access, it was not submitted to the Research Ethics Committee. It is a descriptive study of documentary type, which sought to describe the expansion of the Speech-Language Pathology/ Audiology courses in Brazil through the absolute and relative frequencies of the variables by region of Brazil and by legal nature of $\mathrm{HEI}$. For this, secondary data from the SIGRAS (Sistema de Indicadores das Graduações 
em Saúde - Health Under-graduation Indicator System - http://www.neonet.com.br/sigras_new_mapa/home. php) platform, related to the offer of Speech-Language Pathology/Audiology courses in Brazil, were used.

Data on the number of courses, vacancies, first and final year students were included in the period from 1994 to 2014. The platform, until the date of submission of the present study, did not present data after 2014 . The ratio of applicants to vacancies was obtained by the division of the number of applications by the number of vacancies. These data were stored in tables in the Microsoft Excel ${ }^{\circledR}$ program and analyzed separately according to the regions of Brazil (Central-West, Northeast, North, Southeast and South) and to the legal nature of the Higher Education Institution (HEI) (public and private). The HEls created or incorporated, maintained and managed by the Public Authorities are considered public, and may be federal, state or municipal. Private institutions are HEls maintained and managed by individuals or legal entities under private law.

The ratio of the final-year students of SpeechLanguage Pathology/Audiology courses to million inhabitants by region of Brazil was calculated based on the 1991, 2000 and 2010 demographic censuses provided by the Instituto Brasileiro de Geografia e Estatística (IBGE - Brazilian Institute of Geography and Statistics). Thus, the study variables were: the number of courses, vacancies, first and final year students, applicants to vacancy, final-year students to million inhabitants, regions of Brazil and legal nature of the HEI.

\section{RESULTS}

Table 1 shows the distribution of Speech-Language Pathology/Audiology courses, number of vacancies and applicants to vacancy per region in Brazil. It is observed that there is a concentration of courses in

Table 1. Number of courses, vacancies and applicants per vacancy in Speech-Language Pathology/Audiology by region of Brazil year by year

\begin{tabular}{cccccccccccccccc}
\hline \multirow{2}{*}{ Year } & \multicolumn{1}{c}{ Number of Courses } & \multicolumn{1}{c}{ Number of Vacancies } & \multicolumn{4}{c}{ Applicants per Vacancy } \\
& CW & NE & N & SE & S & CW & NE & N & SE & S & CW & NE & N & SE & S \\
\hline 1994 & 1 & 2 & - & 23 & 7 & 100 & 210 & 0 & 1798 & 510 & 2.0 & 3.5 & - & 2.8 & 1.9 \\
1995 & 1 & 2 & - & 25 & 7 & 110 & 210 & 0 & 2347 & 490 & 3.3 & 3.9 & - & 2.9 & 3.2 \\
1996 & 2 & 3 & - & 26 & 7 & 240 & 210 & 0 & 2228 & 490 & 3.6 & 5.8 & - & 3.1 & 2.7 \\
1997 & 2 & 4 & 1 & 30 & 7 & 270 & 310 & 100 & 2723 & 520 & 3.3 & 4.5 & 5.6 & 3.0 & 2.1 \\
1998 & 3 & 5 & 1 & 36 & 8 & 359 & 373 & 106 & 3622 & 590 & 3.5 & 3.7 & 3.0 & 1.9 & 1.7 \\
1999 & 3 & 11 & 1 & 40 & 9 & 320 & 670 & 108 & 3757 & 650 & 2.9 & 6.9 & 2.7 & 2.1 & 1.4 \\
2000 & 4 & 11 & 2 & 50 & 9 & 400 & 849 & 220 & 4998 & 680 & 1.5 & 4.3 & 2.9 & 1.8 & 1.0 \\
2001 & 5 & 13 & 2 & 55 & 10 & 490 & 1165 & 340 & 4817 & 750 & 1.7 & 4.6 & 1.4 & 1.4 & 1.4 \\
2002 & 6 & 15 & 3 & 61 & 14 & 680 & 1415 & 295 & 4863 & 1180 & 2.8 & 3.3 & 1.7 & 1.8 & 1.1 \\
2003 & 6 & 15 & 3 & 57 & 15 & 658 & 1400 & 380 & 4636 & 1024 & 0.8 & 3.7 & 1.3 & 1.4 & 1.3 \\
2004 & 6 & 16 & 4 & 58 & 15 & 640 & 1460 & 410 & 4718 & 1204 & 0.7 & 2.9 & 3.7 & 1.3 & 1.2 \\
2005 & 6 & 19 & 4 & 57 & 16 & 640 & 1457 & 380 & 4808 & 1024 & 0.6 & 2.4 & 1.8 & 1.3 & 1.0 \\
2006 & 5 & 19 & 4 & 58 & 16 & 436 & 1686 & 330 & 4182 & 789 & 0.6 & 1.7 & 4.9 & 1.3 & 1.1 \\
2007 & 6 & 19 & 5 & 58 & 18 & 840 & 1519 & 615 & 3734 & 1045 & 0.3 & 2.2 & 2.1 & 1.1 & 1.2 \\
2008 & 5 & 19 & 5 & 55 & 17 & 540 & 1514 & 475 & 4950 & 1011 & 0.6 & 1.3 & 1.5 & 0.8 & 1.4 \\
2009 & 5 & 21 & 7 & 44 & 19 & 420 & 2015 & 680 & 3516 & 991 & 0.6 & 1.4 & 1.4 & 1.0 & 1.7 \\
2010 & 6 & 21 & 7 & 41 & 18 & 2338 & 1940 & 650 & 3446 & 964 & 0.9 & 1.3 & 1.2 & 1.2 & 2.0 \\
2011 & 6 & 22 & 7 & 37 & 18 & 1220 & 1720 & 578 & 2925 & 911 & 0.5 & 4.7 & 1.3 & 1.8 & 2.7 \\
2012 & 5 & 22 & 6 & 38 & 18 & 950 & 1488 & 818 & 2361 & 1061 & 0.7 & 5.3 & 1.0 & 2.4 & 2.8 \\
2013 & 5 & 22 & 6 & 35 & 19 & 991 & 1990 & 1196 & 2376 & 1261 & 1.1 & 2.5 & 1.6 & 2.8 & 1.7 \\
2014 & 5 & 21 & 6 & 31 & 19 & 1367 & 1880 & 1367 & 2424 & 1316 & 2.1 & 4.8 & 1.5 & 3.6 & 1.7 \\
\hline
\end{tabular}

Legend: CW - Central-West; NE - Northeast; N - North; SE - Southeast; S - South.

Source: SIGRAS 
the Southeast region. However, from 2014, a decrease in the number of courses in this region is observed. The Northeast had the highest growth in the number of courses. The regions with the lowest concentration of courses are North and Central-West. With regard to vacancies, there is a greater offer in the Southeast than in the other regions. The smallest number is in the North region. Regarding the number of applicants per vacancy, it is noted a greater dispute in the Northeast region.
With regard to the number of first-year students in Speech-Language Pathology/Audiology courses in the different regions of Brazil, it is observed that this number is always smaller than the number of vacancies offered and that the number of final-year students is lower than the number of first-year ones (Table 2).

Regarding the legal nature of the institutions that offer the course, a much larger number of courses in private HEls than in public ones is observed, as seen in Table 3.

Table 2. Number of first and final year students in Speech-Language Pathology/Audiology by region of Brazil year by year

\begin{tabular}{ccccccccccc}
\hline \multirow{2}{*}{ Year } & \multicolumn{9}{c}{ Firs Year Students } & \multicolumn{5}{c}{ Final Year Students } \\
\cline { 2 - 11 } & CO & NE & NO & SE & S & CO & NE & NO & SE & S \\
\hline 1994 & 133 & 551 & - & 1.526 & 439 & 57 & 113 & - & 965 & 96 \\
1995 & 139 & 235 & - & 1.840 & 501 & 52 & 117 & - & 992 & 227 \\
1996 & 284 & 239 & - & 1.756 & 500 & 58 & 151 & - & 1029 & 245 \\
1997 & 272 & 306 & 100 & 2.098 & 574 & 64 & 192 & - & 924 & 198 \\
1998 & 362 & 431 & 102 & 2.427 & 568 & 76 & 150 & - & 936 & 277 \\
1999 & 354 & 715 & 105 & 2.282 & 644 & 105 & 121 & - & 1227 & 344 \\
2000 & 401 & 920 & 230 & 2.355 & 508 & 194 & 177 & - & 1268 & 377 \\
2001 & 486 & 1.081 & 268 & 2.634 & 550 & 262 & 286 & 88 & 1523 & 386 \\
2002 & 431 & 1.324 & 246 & 2.329 & 622 & 210 & 297 & 84 & 1478 & 371 \\
2003 & 433 & 1.074 & 220 & 2.197 & 604 & 195 & 506 & 110 & 1288 & 273 \\
2004 & 194 & 943 & 339 & 1.821 & 568 & 255 & 359 & 116 & 1495 & 256 \\
2005 & 225 & 1.156 & 310 & 1.857 & 548 & 263 & 618 & 122 & 1414 & 235 \\
2006 & 158 & 1.069 & 349 & 1.310 & 462 & 170 & 545 & 113 & 1551 & 303 \\
2007 & 210 & 814 & 502 & 1.314 & 544 & 133 & 486 & 106 & 1006 & 311 \\
2008 & 127 & 680 & 306 & 1.222 & 530 & 111 & 426 & 163 & 1110 & 275 \\
2009 & 91 & 581 & 232 & 1.126 & 325 & 73 & 553 & 140 & 812 & 242 \\
2010 & 137 & 634 & 270 & 970 & 427 & 28 & 490 & 162 & 880 & 291 \\
2011 & 149 & 768 & 369 & 1.052 & 457 & 85 & 378 & 189 & 747 & 200 \\
2012 & 214 & 1.001 & 428 & 1.154 & 546 & 63 & 474 & 125 & 688 & 268 \\
2013 & 391 & 1.022 & 468 & 1.102 & 553 & 32 & 390 & 149 & 743 & 180 \\
2014 & 484 & 988 & 569 & 1.344 & 539 & 57 & 403 & 157 & 569 & 301 \\
\hline
\end{tabular}

Legend: CW - Central-West; NE - Northeast; N - North; SE - Southeast; S - South.

Source: SIGRAS 
Table 3. Number of Speech-Language Pathology/Audiology courses. vacancies. applicants to vacancy. first and final year students by legal nature of the institution year by year

\begin{tabular}{ccccccccccc}
\hline \multirow{2}{*}{ YEAR } & \multicolumn{2}{c}{ Number of Courses } & \multicolumn{2}{c}{ Number of Vacancies } & \multicolumn{3}{c}{ Applicants to Vacancy } & \multicolumn{2}{c}{ First Year Students } & \multicolumn{2}{c}{ Final Year Students } \\
\cline { 2 - 10 } & Public & Private & Public & Private & Public & Private & Public & Private & Public & Private \\
\hline 1994 & 7 & 26 & 278 & 2340 & 9.19 & 0.47 & 280 & 2.369 & 97 & 1134 \\
1995 & 7 & 28 & 318 & 2839 & 10.10 & 0.40 & 282 & 2.433 & 195 & 1193 \\
1996 & 8 & 30 & 298 & 2870 & 9.87 & 0.62 & 299 & 2.48 & 183 & 1300 \\
1997 & 8 & 36 & 338 & 3585 & 8.17 & 0.53 & 331 & 3.019 & 181 & 1197 \\
1998 & 8 & 45 & 338 & 4712 & 8.74 & 0.79 & 346 & 3.544 & 201 & 1238 \\
1999 & 12 & 52 & 500 & 5005 & 13.74 & 0.63 & 497 & 3.603 & 282 & 1515 \\
2000 & 11 & 65 & 387 & 6760 & 11.45 & 0.87 & 396 & 4.018 & 157 & 1859 \\
2001 & 11 & 74 & 388 & 7174 & 11.60 & 0.53 & 398 & 4.621 & 187 & 2358 \\
2002 & 13 & 86 & 448 & 7985 & 10.31 & 1.02 & 472 & 4.480 & 242 & 2198 \\
2003 & 14 & 82 & 478 & 7620 & 9.84 & 0.65 & 528 & 4.000 & 264 & 2108 \\
2004 & 14 & 85 & 482 & 7950 & 8.84 & 0.71 & 513 & 3.352 & 231 & 2250 \\
2005 & 14 & 88 & 465 & 7844 & 7.05 & 0.89 & 475 & 3.621 & 395 & 2257 \\
2006 & 14 & 88 & 514 & 6909 & 7.00 & 0.58 & 512 & 2.836 & 430 & 2252 \\
2007 & 16 & 90 & 600 & 7153 & 5.72 & 0.68 & 616 & 2.768 & 386 & 1656 \\
2008 & 17 & 84 & 630 & 7860 & 4.63 & 0.83 & 656 & 2.209 & 378 & 1707 \\
2009 & 19 & 77 & 760 & 6862 & 4.01 & 0.91 & 728 & 1.627 & 398 & 1422 \\
2010 & 22 & 71 & 952 & 8386 & 4.03 & 0.66 & 975 & 1.463 & 551 & 1300 \\
2011 & 23 & 67 & 1001 & 6353 & 10.77 & 0.36 & 1.007 & 1.788 & 499 & 1100 \\
2012 & 23 & 66 & 1009 & 5669 & 10.36 & 0.48 & 1.055 & 2.288 & 495 & 1123 \\
2013 & 24 & 63 & 1288 & 6526 & 4.80 & 1.39 & 1.059 & 2.477 & 562 & 932 \\
2014 & 24 & 58 & 1255 & 7099 & 7.98 & 1.87 & 1.025 & 2.899 & 606 & 881 \\
\hline
\end{tabular}

Source: SIGRAS

In private institutions, the number of courses reached the peak in 2007. Since then, the offer of courses in private institutions decreased. The number of courses in public institutions increased in this period, with the exception of municipal institutions, since the last one to offer the Speech-Language Pathology/ Audiology course ceased this offer in 1999.

The distribution of vacancies, according to the legal nature of the institution, reveals that, in the first decade analyzed (1994-2004), there was an intense growth in the private sphere and a lower growth of the vacancies in public institutions. In the second decade analyzed (2004-2014), there was a greater growth of vacancies in public institutions in comparison to the previous period.
The largest number of students enrolled in the course took place in private institutions during the analyzed period. Regarding the ratio of applicants to vacancy, the competition is greater in the public institutions than in the private ones.

Table 4 presents the ratio of final-year students of Speech-Language Pathology/Audiology courses to each million inhabitants by region of Brazil, based on the demographic censuses of 1991, 2000 and 2010. Overall, there was a $57.6 \%$ increase in the number of final-year students to million inhabitants in the first analyzed decade, followed by a decrease of $18.28 \%$ in the second analyzed one. The ratio of final-year students to inhabitant is higher in the Southeast. 
Table 4. Ratio of the final year students of Speech-Language Pathology/Audiology courses to inhabitants by region of Brazil in the years 1991, 2000 and 2010

\begin{tabular}{ccccc}
\hline & Year & $\mathbf{1 9 9 1}$ & $\mathbf{2 0 0 0}$ & $\mathbf{2 0 1 0}$ \\
\hline \multirow{3}{*}{ Central-West } & Population & $9,427,601$ & $11,636,728$ & $14,058,094$ \\
& Final Year Students & 27 & 194 & 28 \\
& Final Year/inhabitants & 2.86 & 16.67 & 1.99 \\
\hline \multirow{3}{*}{ Northeast } & Population & $42,497,540$ & $47,741,711$ & $53,081,950$ \\
& Final Year Students & 129 & 177 & 490 \\
& Final Year/inhabitants & 3.04 & 3.71 & 9.23 \\
\hline \multirow{3}{*}{ North } & Population & $10,030,556$ & $12,900,704$ & $15,864,454$ \\
& Final Year Students & 0 & 0 & 162 \\
& Final Year/inhabitants & 0 & 0 & 10.21 \\
\hline \multirow{3}{*}{ Southeast } & Population & $62,740,401$ & $72,412,411$ & $80,364,410$ \\
& Final Year Students & 836 & 1268 & 880 \\
& Final Year/inhabitants & 13.32 & 17.51 & 10.95 \\
\hline \multirow{3}{*}{ South } & Population & $22,129,377$ & $25,107,616$ & $27,386,891$ \\
& Final Year Students & 113 & 377 & 291 \\
& Final Year/inhabitants & 5.11 & 15.02 & 10.63 \\
\hline \multirow{2}{*}{ Brasil } & Population & $146,825,475$ & $169,799,170$ & $190,755,799$ \\
& Final Year Students & 1105 & 2016 & 1851 \\
& Final Year/inhabitants & 7.53 & 11.87 & 9.70 \\
\hline
\end{tabular}

Source: IBGE, Demographic Census 1991/2010

\section{DISCUSSION}

The number of Speech-Language Pathology/ Audiology courses in the country is higher in the Southeast region, possibly explained by the economic development and great population density. The first courses in Speech-Language Pathology/Audiology in Brazil appeared in this region ${ }^{1}$. The Southeast region accounted for $70 \%$ of the courses in 1994 , decreasing to $37.8 \%$ in 2014 , but this number is still different from that of other regions, confirming the regional imbalance of professional training opportunities in the health area and indicating the need of incentive policies to reduce inequalities. The regions with the lowest concentration of courses are Central-West and North. The latter received the first Speech-Language Pathology/ Audiology course only in 1997. The vacancies offered in the Speech-Language Pathology/Audiology courses follow the distribution profile of the number of courses per region. The highest number of applicants per vacancy in Speech-Language Pathology/Audiology courses is in the Northeast region, which can be explained by the small offer of vacancies in the region - the second largest in population size. There was a progressive increase in the number of vacancies in the Northeast during the period analyzed and a consequent decrease in the rate of candidates per vacancy.
The number of first-year students in the SpeechLanguage Pathology/Audiology courses is lower than that of vacancies, suggesting idleness in all regions of Brazil. This finding agrees with the study by Crestani et al. ${ }^{5}$, which shows that the supply of vacancies is greater than the demand. The fact that the number of final-year students is lower than the number of first-year students is also pointed out in the literature ${ }^{5}$. According to Crestani et al. ${ }^{5}$, the rate of dropout in Brazilian higher education is generally high. The authors suggest that the overwhelming predominance of the private sector, coupled with the low attractiveness of the market and low quality in the teaching-learning processes, do not allow the student to remain until graduation.

Most courses and vacancies are concentrated in the private sector, which, in 2014 , had $85 \%$ of the vacancies and $70.7 \%$ of the Speech-Language Pathology/Audiology courses in Brazil. Consequently, most Brazilian speech-language pathologists/audiologists come from private HEls. This is not just a reality of Speech Pathology/Audiology: the higher education system in Brazil, in general, is predominantly private, between $70 \%$ and $80 \%$. In a survey about the distribution of undergraduate students in Latin America in 2009, according to the administrative nature of the establishment, it was found that $52 \%$ of Latino students are in private institutions. In Brazil, this figure rises to 
$77 \%$, only getting behind Chile whose higher education was only in the private sector ${ }^{8}$. The most important criterion for the offer of courses in the private institutions is financial ${ }^{9}$. This makes the richer regions have a large number of courses with greater commercial appeal, while certain professional areas that need reinforcements are neglected ${ }^{9}$. However, the number of vacancies in the private institutions decreased from 8,386 (peak in 2010) to 7,099 (2014) (15.3\% drop) and the number of courses reduced from 86 (peak in $2002)$ to 58 (2014, 32.5\% drop). This decrease can be explained by the low demand for the course, which, in turn, can be attributed to the low recognition and appreciation in the labor market ${ }^{10-12}$. Authors point to the positive and significant effect of the average salary factor of the profession on the professional choice $^{13}$. This decrease in the demand for the course does not seem to be Brazilian exclusivity, since it is also observed in other countries, including developed ones, such as the United States ${ }^{14}$. Another factor that can contribute to the low demand is the social prestige, considered low (seventh/eighth position in a scale of thirteen professions) ${ }^{15}$.

In the first analyzed decade, there was an increase in vacancies in the private HEls, while in the second decade there was an increase in the number of vacancies in the public HEls. This change can be explained by the Brazilian political scenario that, in the historical series analyzed, is composed of two phases: the first related to the government of Fernando Henrique Cardoso (1995-2002), and the second, to that of Luiz Inácio Lula da Silva (2003 -2010). In the government of Fernando Henrique Cardoso, the State Reform defined the rationality with respect to public policies, including the Higher Education. Therefore, it is a phase of great expansion of courses in the private sector and small evolution in the public sector ${ }^{9}$, although the origin of the growth of the private sector over the public one goes back to the times of the civil-military dictatorship (19641984), due to the university reform instituted by law no. 5,540/1968. This legislation reinforced the performance of the then Conselho Federal de Educação (Federal Council of Education), with a strong privatization composition, and tax incentives were created for the opening of private HEls ${ }^{9}$. In the first term of Lula's administration (2003-2006), social policies remained timid as a way of balancing the country's budget, and the higher education policy remained similar to that of the previous government ${ }^{16}$. During this period, the Universidade para todos (PROUNI - University for All) Program was established through Law 11,096/2005, with the purpose of democratizing the teaching through the granting of scholarships in undergraduate courses in private HEls. The second term of Lula administration (2007-2010) was differentiated from the first by the expansion of public higher education through the Programa de Apoio a Planos de Reestruturação e Expansão das Universidades Federais (REUNI Support Program to Restructuring and Expansion Plans of the Federal Universities), instituted by Decree No. 6,096 in 2007 and which culminated in the creation of new public universities and expansion of the existing ones $^{17}$.

Unlike the private sector, which is guided by the law of supply and demand, in the public sector, the Sistema Único de Saúde (SUS - Brazilian public health service) has the responsibility to order the formation of human resources for the health area, according to art. 200 , section III of the Brazilian Constitution. For this, the Ministério da Saúde (Department of Health) developed and supported several actions in the field of training and development of health professionals over the time ${ }^{7}$. Thus, while there was a decrease in the number of vacancies and private courses, the public sector experienced increase of vacancies. Nevertheless, in 2014, 13 Brazilian states did not have a Speech-Language Pathology/Audiology course offered at a public institution. They were: Goiás, Mato Grosso, Amazonas, Ceará, Maranhão, Pará, Piauí, Rondônia, Mato Grosso do Sul, Acre, Amapá, Roraima and Tocantins. The last five ones did not have the offer of the course in private institutions either. The high ratio of applicant to vacancy in the public institutions, in comparison with the private ones, also occurs in the other courses of the health area. Some authors state that this high ratio results in improvement of the level of the applicants entering the public institutions ${ }^{5}$.

Students with lower cultural repertoire may be entering the private system, favored or not by incentive programs such as PROUNI, the Fundo de Financiamento Estudantil (FIES - Student Financing Fund) and the existence of policies of university quotas. The entry of these students into private institutions, when not favored by incentive programs, generates the need to work, which can reduce the quality of the learning or even increase the dropout. PROUNI gradually increased the number of scholarships offered in private institutions between 2005 and 2014 ${ }^{18}$. However, as already mentioned, there was reduction of vacancies and courses of Speech-Language Pathology/ Audiology during this period. This may mean that these courses were not significantly covered by PROUNI, or 
that, even with this incentive, the applicants were not interested enough to attend the course on the private sector.

Despite the low demand for the course, the field of intervention of the speech pathologist/audiologist has expanded considerably in recent years. Ministerial Order 154/2008 inserted the speech pathologist/audiologist among the occupations that may comprise the Núcleo de Apoio à Saúde da Família (NASF - Family Health Support Center). Law 12,303/2010 established the obligation to perform universal neonatal hearing screening in all children born in hospitals and maternity hospitals throughout Brazil. Other health policies that favored a greater insertion of speech-language/ audiology care in the Sistema Único de Saúde (SUS - Brazilian public health service) were the following ones: Política Nacional de Atenção Auditiva (National Policy on Hearing Care), Programa Saúde na Escola (Health in School Program) and Programa Viver sem Limites (Living Without Limits Program). In 2015, the Conselho Federal de Fonoaudiologia (CFFa - Federal Speech-Language Pathology/Audiology Council), in Resolution 469, established the competence of the speech-language pathologist to implement, monitor, advise, supervise and coordinate Hearing Loss Prevention Programs. New specializations were recognized by CFFa, such as Educational Speech-Language Pathology and Dysphagia, in 2010 (RESOLUTION CFFa no. 382/2010), and Neuropsychology, Gerontology, Labor Speech-Language Pathology/Audiology and Neuro-functional Speech-Language Pathology, in 2014 (RESOLUTION CFFa no 453/2014). Besides, the number of professionals is still deficient in relation to the national needs. One study points to the discrepancy in the number of speech pathologists working in the SUS, showing a deficit of $82.4 \%$ of professionals in the year 2000 and $56.8 \%$ in 2010 . The North and Northeast regions presented, between 2000 and 2010, deficits higher than the national one, and the South and Southeast regions presented the lowest deficits ${ }^{19}$.

The ratio of final-year students to inhabitants is higher in the Southeast. There was an increase in this indicator to every one million inhabitants from 1991 to 2000 , followed by a decrease in the Central-West, Southeast and South regions in 2010. In the Northeast, the growth was progressive. According to some authors $^{7}$, the lowest number of final-year students to inhabitants among the health courses is the SpeechLanguage Pathology/Audiology course one. It is speculated that there will be an increase in the demand for speech-language pathologists/audiologists in the coming decades, as advances in the medical field provide a higher life expectancy with a consequent increase in the elderly population, as well as an increase in the survival rate of preterm babies and of victims of trauma and stroke. Other factors include policies for early identification of alterations such as the universal neonatal hearing screening and the inclusion of people with special needs in the regular education ${ }^{10}$.

The limitations of this study were the absence, in the SIGRAS platform, of data prior to 1991 and after 2014, as well as the exclusive use of secondary data. According to Miranda ${ }^{19}$, this type of data is a good strategy for the research development, because it optimizes time. However, these data carry limitations such as the loss of context and of the intentions that guided their collection. In the specific case of the SIGRAS platform, it should be noted that this is a platform of secondary data that were tabulated from another secondary source - the Censo da Educação Superior (Higher Education Census), formulated by the Instituto Nacional de Estudos e Pesquisas Educacionais Anísio Teixeira (INEP - National Institute of Educational Studies and Research Anísio Teixeira). Since not all the variables present in this source were tabulated in the SIGRAS platform, there is no way to use it to answer all possible research questions. As a strong point of the research, there is the theme that is pertinent to the current moment, due to the economic crisis that Brazil has passed since 2015 and that negatively affects the entrance of students in undergraduate courses in general. It is probable that future studies will show a change in the current panorama of education in Speech-Language Pathology/Audiology and it is necessary to have up-to-date information always available to speech-language pathologists/ audiologists who wish to understand the trajectory of their course.

Knowing the expansion process of SpeechLanguage Pathology/Audiology training makes it possible to identify the paths taken to project new directions for the profession aiming at the development and the obtaining of technical-scientific and social recognition for the area. It is hoped that the results here presented may support further studies on the training of the Speech-Language Pathology/Audiology professional and may contribute to the planning and implementation of professional training policies in the search for a reduction of regional inequalities and for a greater professional appreciation. 


\section{CONCLUSION}

The number of courses, vacancies, first and final year students in Speech-Language Pathology/ Audiology was higher in the Southeast region of the country. Since 2008/2009, in the analyzed period, there was a decrease in the number of courses and vacancies in the Southeast region and a progressive increase in the Northeast and South regions of the country. Most of the courses, vacancies, first and final year students were in private educational institutions. However, this number decreased, while the number of public institutions that offer the course increased. The ratio of applicants to vacancy in the educational institutions was higher in the Northeast region, due to the low vacancy offer in the region, being higher in the public sector than in the private one. There was an increase in the number of first-year students per million inhabitants in the first analyzed decade, followed by a decrease in the second decade analyzed.

It is hoped that this work contributes to the planning and implementation of higher education training policies in Speech-Language Pathology/Audiology, in the search for the reduction of inequalities among the regions of Brazil.

\section{ACKNOWLEDGEMENTS}

The authors acknowledge support from Pró-Reitoria de Pesquisa da UFMG.

\section{REFERENCES}

1. Aarão PCL, Pereira FCB, Seixas KL, Silva HG, Campos FR, Tavares APN et al. Speech therapy history: a report on some brazilian states. Rev Med Minas Gerais. 2011;21(2):238-44.

2. Haddad AA, Pierantoni CR, Ristoff D, Xavier IM, Giolo J, Silva LB. A trajetória dos cursos de graduação na área da saúde: 1991-2004. Instituto Nacional de Estudos e Pesquisas Educacionais Anísio Teixeira: Brasília; 2006.

3. Brasil. Lei 6.965 de 09/12/1981. Brasília (DF); 1981.

4. Conselho Federal de Fonoaudiologia. Número de fonoaudiólogos no Brasil por Conselho Regional. Brasília (DF); 2015b. Disponível em: http://www. fonoaudiologia.org.br/cffa/index.php/numero-porregiao/ acessado em 29/01/2016.

5. Crestani AH, Souza APR, Plaza E, Fedosse E, Vendrúsculo JF, Costa VBR. Graduation in speech therapy and audiology: considerations about the reality in Brazil and Chile. Distúrb. Comum. 2014;26(3):428-38.
6. Bacha SMCB, Osório AMN. Fonoaudiologia e educação: uma revisão da prática histórica. Rev. CEFAC. 2004;6(2):215-21.

7. Haddad AE, Morita MC, Pierantoni CR, Brenelli SL, Passarella T, Campos FE. Undergraduate programs for health professionals in Brazil: an analysis from 1991 to 2008. Rev Saúde Públ. 2010;44(3):383-93.

8. Pereyra A. The fragmentation of the educational offer in Latin America: public vs private education. Perfiles Educativos. 2008;30(120):132-46.

9. Mancebo D, Vale AA, Martins TB. Expansion of higher education policy in Brazil: 1995-2010. Rev Bras Educ. 2015;20(60):31-50.

10. Guigen AP, Zabeu JS, Freire T, Campos PD, BerretinFelix G, Ferrari DV. Speech language pathology and audiology as a higher education option: exploratory study. Rev. CEFAC. 2014;16(3):974-84.

11. Fonteles IBA, Friedman S, Haguiara-Carvellini N. Fonoaudiologia: inserção em instituições educacionais de Salvador. Disturb. Comun. 2009;21(1):55-65.

12. Teixeira LC, Rodrigues ALV, Santos JN, Cardoso AFR, Gama ACC, Resende LM. Professional trajectory of graduates in speech, language and hearing sciences. Rev. CEFAC. 2013;15(6):1591-600.

13. Bartalotti $O$, Menezes-Filho N. A relação entre $O$ desempenho da carreira no mercado de trabalho e a escolha profissional dos jovens. Econ aplic. 2007;11(4):487-505.

14. Emanuel DC, Donai JJ, Araj CF. The awareness of the profession of audiology among entering. Am J Audiol. 2012;21:41-50.

15. Sousa FAEF, Silva JA. Nurses' professional prestigie: estimation of magnitudes and expanded categories. Rev Latino-am Enfermagem. 2001;9(6):19-24.

16. Prestes EMT, Jezine E, Scocuglia AC. Democratização do ensino superior brasileiro: o caso da Universidade Federal da Paraíba. Rev Lusofona. 2012;21(21):199-218.

17. Araújo CB, Santos LMM. The reuni in the perspective of the public university's managers. Psicol Soc. 2014;26(3):642-51.

18. SISPROUNI, 2015. Bolsas ofertadas por ano. Disponível em http://prouniportal.mec.gov.br/

19. Miranda GMD, Mendes ACG, Silva ALA, Rodrigues M. Phonoaudiological care in SUS: expanding access and the challenge of overcoming inequalities. Rev. CEFAC. 2015;17(1):71-9. 